\title{
Mango and diabetes
}

\author{
Bharti Kalra, Lovely Gupta ${ }^{1}$, Deepak Khandelwal' ${ }^{2}$, Nishant Choubey ${ }^{3}$
}

Department of Gynecology, Bharti Hospital, Karnal, ${ }^{3}$ Department of Culinary Science, The Roseate, Gurgaon, Haryana, ${ }^{1}$ Department of Dietetics, Maharaja Agrasen Hospital, '2Department of Endocrinology, Maharaja Agrasen Hospital, New Delhi, India

Abstract

The mango is considered as the king of fruits. It is one of the most consumed seasonal fruits in South Asia. Most persons with diabetes and health-care providers assume that mango should be strictly avoided by persons with diabetes. However, mango is a fruit with good nutritive value, low glycemic load as well as with acceptable glycemic index. In this short review, we summarize the nutritive values of mango, as well as the ways in which mangoes can be enjoyed, in moderation, by persons with diabetes.

Keywords: Diabetes, fruits, glycemic index, mango

Address for correspondence: Dr. Bharti Kalra, Department of Gynecology, Bharti Hospital, Karnal, Haryana, India.

E-mail: brideknl@gmail.com

Received: 10.08.2017, Accepted: 10.08.2017

\section{INTRODUCTION}

The mango is considered as the king of fruits by all. For people with diabetes, however, it is thought to be the Menaka of fruits. Irresistible because of its taste, it is thought to lure its consumers to metabolic doom. In this way, it is similar to the fairy (apsara) Menaka, who seduced the venerable sage, Vishvamitra, and interrupted his meditation. Our brief communication aims to correct this misconception.

\section{SOURCE}

The mango is a fruit of the Mangifera tree. It can be eaten raw or ripe. Mango is the national tree of Bangladesh, as well as the national fruit of India, Pakistan, and the Philippines. Apart from these countries, it is majorly produced in China, Thailand, Indonesia, and Mexico as well.

\section{NUTRITIONAL VALUE}

The mango has been the subject of much research in clinical nutrition. The mango provides all the significant

\begin{tabular}{|l|l|}
\hline \multicolumn{2}{|c|}{ Access this article online } \\
\hline Quick Response Code: & Website: \\
\hline & www.joshd.net \\
\cline { 2 - 2 } & DOI: \\
& 10.4103/joshd.J_Soc_Health_ \\
\hline
\end{tabular}

Vitamins A, B, C, and $\mathrm{K}$ along with calcium, iron, copper, and potassium, respectively [Table 1]. There is no cholesterol in mango. ${ }^{[1]}$

The glycemic load of mango is 51 , which is classified as low. Its glycemic index has been found to be similar to that of other tropical and subtropical fruits. ${ }^{[2]}$

Mangiferin, a bioactive substance found in mango seeds $(0.42 \mathrm{mg} / \mathrm{kg})$, peel $(1690.4 \mathrm{mg} / \mathrm{kg})$, and pulp $(4.4 \mathrm{mg} / \mathrm{kg})$, is thought to have hypoglycemic properties. Mangiferin is a xanthone with high antioxidative activity. It inhibits sucrase, isomaltase, and maltase, and thus decreases in glucose intestinal absorption. Mango also contains dietary fiber, which can reduce digestion of carbohydrate and lower glucose absorption. ${ }^{[3]}$

\section{EVIDENCE}

Human studies suggest that mango consumption may improve postprandial glucose and markers of

This is an open access journal, and articles are distributed under the terms of the Creative Commons Attribution-NonCommercial-ShareAlike 4.0 License, which allows others to remix, tweak, and build upon the work non-commercially, as long as appropriate credit is given and the new creations are licensed under the identical terms.

For reprints contact: reprints@medknow.com

How to cite this article: Kalra B, Gupta L, Khandelwal D, Choubey N. Mango and diabetes. J Soc Health Diabetes 2018;6:56-8. 
Table 1: Nutritional value of mango $(/ 100 \mathrm{~g})^{[11]}$

\begin{tabular}{ll}
\hline Nutrient & Quantity \\
\hline Energy & $74 \mathrm{kcal}$ \\
Carbohydrates & $16.9 \mathrm{~g}$ \\
Moisture & $81 \mathrm{~g}$ \\
Crude fiber & $0.7 \mathrm{~g}$ \\
Fat & $0.4 \mathrm{~g}$ \\
Protein & $0.6 \mathrm{~g}$ \\
Vitamins & \\
Carotene & $2743 \mathrm{mg}$ \\
Thiamine (B1) & $0.08 \mathrm{mg}$ \\
Riboflavin (B2) & $0.09 \mathrm{mg}$ \\
Vitamin C & $16 \mathrm{mg}$ \\
Vitamin E & $0.9 \mathrm{mg}$ \\
Vitamin K & $4.2 \mathrm{mcg}$ \\
Minerals & \\
Magnesium & $270 \mathrm{mg}$ \\
Manganese & $0.13 \mathrm{mg}$ \\
Phosphorus & $16 \mathrm{mg}$ \\
Potassium & $205 \mathrm{mg}$ \\
Calcium & $14 \mathrm{mg}$ \\
Phosphorus & $16 \mathrm{mg}$ \\
Iron & $1.3 \mathrm{mg}$ \\
Copper & $0.11 \mathrm{mg}$ \\
Sodium & $26 \mathrm{mg}$ \\
\hline
\end{tabular}

atherosclerosis. Mango consumption for 42 days has been shown to decrease systolic blood pressure in lean subjects, but not in obese persons. Hemoglobin A1C improves significantly in obese but not lean subjects. Reduced expression of PAI-1, associated with reduced risk of atherosclerosis and thrombosis, is observed in both lean and obese individual. ${ }^{[4]}$

Pre-packaged ground freeze-dried ripe "Tommy Atkins" mango fruit powder has been shown to improve glucose values and increase insulin levels in obese diabetics. ${ }^{[5]} \mathrm{A}$ similar trend is noted in prediabetic individuals. ${ }^{\left[{ }^{[6]}\right.}$

\section{USAGE}

Logical empiricism suggests that mango should not be banned from the diabetic menu. One should follow a person-centered counseling approach to mango consumption in persons with diabetes. Depending on the glycemic control, people may consume small portions of the fruit approx. 100-150 $\mathrm{g}$ of edible portion/day or $50 \mathrm{~g}$ mango slice thrice a day which is friendlier to glucose metabolism than a larger portion of it consumed with the heaviest meal.

The glycemic index may be further lowered by taking mango after consumption of high fiber food such as salads or beans or whole grains. Dicing the fruit into small cubes or thin slices increases its surface area, thus improving palatability and taste while keeping the total consumption within limits. Processing of mango puree by high hydrostatic pressure also reduces its glycemic index. ${ }^{[7]}$
Mangoes are weighed and bought by the kilogram. This makes it easy to explain the concept of serving size, and glycemic load calculation, to the average consumer. One must note that the peel and seed contribute to about $20 \%-25 \%$ of the total weight of the fruit. Mango peel, leaves, and mango kernel flour have been used to modulate glycemia in animal models, but are not part of South Asian diet. $^{[8-10]}$

\section{RECIPES}

Mango is a versatile fruit which is a gift to the chef. It adds taste, color, flavor, and variety to recipes and can be used in raw as well as cooked form. It can be grilled, boiled, steamed, roasted, baked, as well as stewed. Beverages such as aam panna or mango kanji can also be prepared from mango pulp. Tasty and healthy recipes which allow people with diabetes to taste its flavor include mango and cucumber salads, baked mango tart with mushroom, mango and dried nuts, mango salsa, and steamed mango idli. Boiled mango can be used to make sauces with a garnishing of chia seed, flax seed, and aniseed. Raw mango slices can be dusted with a starch and can be turned into a fritter, a great snack. Mango can be added as a natural sweetening agent to desserts, obviating the need for sugar.

\section{SUMMARY}

Mangoes may be eaten in moderation by persons with diabetes. While they are purported to have multiple benefits on metabolism, one must be mindful of total caloric intake, portion size, frequency and glycemic load, while consuming this fruit.

Financial support and sponsorship

Nil.

\section{Conflicts of interest}

There are no conflicts of interest.

\section{REFERENCES}

1. Mango. Available from: https://www.ndb.nal.usda.gov/ndb/ nutrients/. [Last accessed on 2017 Jul 23].

2. Oboh G, Ademosun AO, Akinleye M, Omojokun OS, Boligon AA, Athayde ML. Starch composition, glycemic indices, phenolic constituents, and antioxidative and antidiabetic properties of some common tropical fruits. J Ethnic Foods 2015;2:64-73.

3. Masibo M, Qian H. Major mango polyphenols and their potential significance to human health. Compr Rev Food Sci Food Saf 2008;7:309-19.

4. Fang C, Kim H, Barnes R, Talcott ST, Mertens-Talcott SU. Daily mango (Mangifera indica L.) Consumption for 42 days differentially modulates metabolism and inflammation in lean and obese individuals. FASEB J 2017;31 1 Suppl: 431-3.

5. Evans SF, Meister M, Mahmood M, Eldoumi H, Peterson S, 
Perkins-Veazie P, et al. Mango supplementation improves blood glucose in obese individuals. Nutr Metab Insights 2014;7:77-84.

6. Semkoff J, Evans S, Janthachotikun S, Eldoumi H, Mahmood M, Meister M, et al. The effect of mango supplementation on clinical parameters of pre-diabetic individuals. FASEB J 2015;29 1 Suppl:602-12.

7. Elizondo-Montemayor L, Hernández-Brenes C, Ramos-Parra PA, Moreno-Sánchez D, Nieblas B, Rosas-Pérez AM, et al. High hydrostatic pressure processing reduces the glycemic index of fresh mango puree in healthy subjects. Food Funct 2015;6:1352-60.

8. Gondi M, Prasada Rao UJ. Ethanol extract of mango (Mangifera indica L.) peel inhibits $\alpha$-amylase and $\alpha$-glucosidase activities, and ameliorates diabetes related biochemical parameters in streptozotocin (STZ)-induced diabetic rats. J Food Sci Technol 2015;52:7883-93.

9. Lakshmi M, Usha R, Preetha R. Mango (Mangifera indica) stone kernel flour - A novel food ingredient. Malays J Nutr 2016;22:461-7.

10. Patnaik R. Mango leaves in treating diabetes: A strategic study. Int J Innov Res Dev 2014;3(12):432-441.

11. Available from: http://www.icmr.nic.in/pricepubl/content/1.htm. [Last accessed on 2017 Aug 09]. 